\title{
PENGARUH CITRA MEREK DAN POTONGAN HARGA TERHADAP MINAT BELI (Studi Kasus Pada Distro Three Second di Kota Cilegon)
}

\author{
Muhamad Suhaemi \\ Fakultas Ekonomi Dan Bisnis Universitas Serang Raya \\ eganjaka@yahoo.com
}

\begin{abstract}
Competition in the business world is a challenge for the three second, three second always displays clothing models that are characteristic of young people, three second is a distribution that is well known among the public, especially in the city of Cilegon. (1) Is there an effect of brand image on buying interest in three second distribution in Cilegon City (2) Is there an effect of price discount on buying interest in three second distribution in Cilegon City (3) Is there an effect of brand image and price discount on buying interest. This study aims to examine the effect of brand image and price discounts on buying interest in a three second distribution in the city of Cilegon. The data collection method used was a questionnaire, with a population of 122 people, the number of samples used in this study were 94 people. Then the data were analyzed with SPSS version 2.0. (1) the results of the calculation show a significance value of $0.00<0.05$ or Tcount 4.034> $1.661 \mathrm{~T}$ table can be stated that brand image has an effect on buying interest. (2) the calculation shows a significance value of $0.00<0.05$ or Tcount 4.297> 1.661 T table, thus that the price discount is quite influential on buying interest. (3) The results of statistical calculations show 14,906> 3.10 F table with a significant level of $0.000<0.05$, so Ho is rejected. So with this it can be concluded that the variable Brand Image (X1) and Price Discounts (X2) simultaneously have a significant effect on Purchase Interest (Y).
\end{abstract}

Keywords : Brand Image, Discount, Purchase Intention

\begin{abstract}
ABSTRAK
Persaingan dalam dunia bisnis menjadi tantangan tersendiri bagi three second, three second selalu menampilkan modelmodel pakaian yang menjadi ciri khas kalangan anak muda, three second merupakan salah satu distro yang cukup dikenal dikalangan masyarakat terutama diKota Cilegon. (1) Apakah terdapat pengaruh citra merek terhadap minat beli pada distrothree second diKota Cilegon (2) Apakah terdapat pengaruh potongan harga terhadap minat beli pada distrothree second diKota Cilegon (3) Apakah terdapat pengaruh citra merek dan potongan harga terhadap minat beli. Penelitian ini bertujuan untuk menguji pengaruh citra merek dan potongan harga terhadap minat beli pada distro three second diKota Cilegon.Metode pengumpulan data yang digunakan adalah kuesioner, Dengan populasi 122 orang, jumlah sampel yang digunakan penelitian ini sebanyak 94 orang.Kemudian data dianalisis dengan SPSS versi 2.0 . (1)hasil perhitungan menunjukan nilai signifikansi $0,00<0,05$ atau $\mathrm{T}_{\text {hitung }} 4,034>1,661 \mathrm{~T}_{\text {tabel }}$ dapat dinyatakan bahwa citra merek berpengaruh dalam minat beli. (2)dari perhitungan menunjukan nilai signifikansi $0,00<0,05$ atau $\mathrm{T}_{\text {hitung }}$ 4,297 > 1,661 $\mathrm{T}_{\text {tabel }}$ dengan demikian bahwa potongan harga cukup berpengaruh terhadap minat beli. (3)Hasil Perhitungan Statistik menunjukan $14.906>3,10 \mathrm{~F}_{\text {tabel }}$ dengan tingkat signifikan sebesar $0,000<0,05$ maka Ho ditolak. Maka dengan ini dapat disimpulkan bahwa variabel Citra Merek $\left(\mathrm{X}_{1}\right)$ dan Potongan Harga $\left(\mathrm{X}_{2}\right)$ secara simultan berpengaruh signifikan terhadap Minat Beli (Y).
\end{abstract}

Kata Kunci: Citra Merek, Potongan Harga, Minat Beli

\section{PENDAHULUAN}

Produk Three Second memiliki desain gambar yang unik dengan menampilkan desain yang stylish selain itu Three second juga memiliki kulaitas bahan yang baik sehingga memiliki rasa nyaman dan elegan ketika hendak memakai produk tersebut.

Salah satu bauran pemasaran yang dilakukan oleh distro Three second yang berada di kota Cilegon yaitu dengan melakukan event-event diskon dalam satu bulan dua kali antara lain diskon yang sering diadakan oleh pihak three second dikota cilegon yaitu diskon $20 \%$ all item dan diskon yang tidak sering dilakukan yaitu diskon $30 \%$ 50\%. Hingga $70 \%$.

Menanggapi tingginya daya beli masyarakat kota Cilegon dalam 
menggunakan pakaian maka produsen produsen berlomba-lomba untuk menciptakan fashion yang dimana sudah tersebar di berbagai di kota Cilegon, berbagai macam macam brand distro di Kota Cilegon memiliki segmentasi yang bertujuan untuk mencari konsumen dikalangan pelajar, mahasiswa, pekerja hingga dikalangan anak-anak.

Wijaya (2011) Citra merek adalah apa yang konsumen pikirkan dan rasakan ketika mendengar atau melihat nama suatu merek. Atau dengan kata lain, citra merek merupakan bentuk atau gambaran tertentu dari suatu jejak makna yang tertinggal di benak khalayak konsumen

Menurut Sutisna (2002:302) discount atau potongan harga adalah pengurangan harga produk dari harga normal dalam periode tertentu.

Dalam jurnal Sudrajat (2017). Kotler \& Keller (2012 : 131). Minat Beli merupakan sebuah perilaku konsumen yang dimana konsumen mempunyai keinginan dalam membeli atau memilih suatu produk, berdasarkan pengalaman dalam memilih menggunakan dan mengkonsumsi bahkan dalam memilih atau menggunakan dan mengkonsumsi atau dalam menginginkan suatu produk tersebut.

Penelitian ini dilakukan dilingkungan masyarakat Kota Cilegon dipilihnya objek tersebut karena masyarakat kota cilegon memiliki citra merek akan adanya distro three second sangat tinggi, dibandingkan distrodistro kompetitornya apalagi dengan adanya potongan harga, masyarakat kota cilegon memiliki minat pembelian terhadap produk three second.

Sehingga minat peneliti untuk melakukan penelitian terhadap distro clothing. Yang berjudul "Pengaruh Citra Merek Dan Potongan Harga Terhadap Minat Beli . (Studi Kasus Pada Distro Three Second Cilegon)".

\section{METODOLOGI PENELITIAN}

Populasi adalah sekelompok orang, kejadian atau apapun yang menjadi perhatian peneliti untuk membuat inferensi (berdasarkan sampel).populasi yang digunakan adalah konsumen distro three second diKota Cilegon,

Dalam Roscoe yang dikutip Sekaran (2013:276) memberikan acuan umum untuk menenirukan ukuransampel:

1. Ukuran sampel lebih dari 30 dan kurang dari 500 adalah tepat untuk kebanyakanpenelitian.

2. Jika sampel dipecah ke dalam subsampel (pria/wanita, junior/senior, dan sebagainya), ukuran sampel minimum 30 untuk tiap kategori adalahtepat.

3. Dalam penelitian multivariate (termasuk analisis regresi berganda), ukuran sampel sebaiknya 10 kali lebih besar dari jumlah variabel dalam penelitian.

4. Untuk penelitian eksperimental sederhana dengan kontrol eskperimen yang ketat, penelitian yang sukses adalah mungkin dengan ukuran sampel kecil antara 10 sampai dengan20.

Oleh karena itu teknik sampling yang digunakan adalah purposive sampling, maka pada kuesioner peneliti menanyakan terlebih dahulu apakah responden adalah konsumen three second di kota cilegon. Berdasarkan pada teori Roscoe tersebut lebih tepatnya mengacu pada teori Roscoe nomor satu, maka peneliti menetapkan jumlah sampel sebanyak 94 orang responden, karena angka 94 sudah cukup untuk menjadi sampel penelitian ini dan telah memenuhisyarat.

Menurut Ghozali (2018) uji validitas digunakan untuk mengukur sah atau valid tidaknya suatu kuesioner.suatu item dianggap valid jika berkorelasi signifikan terhadap skor total. Nilai uji akan dibuktikan dengan menggunakan uji dua sisi tarif 
signifikan 0,05 SPSS akan secara default menggunakan nilai ini.

Menurut Ghazali (2018:45)

Reliabilitas sebenernya adalah alat untuk mengukur suatu kuesioner yang merupakan indicator dari variabel atau kunstruk, Mengukur Reliabilitas dengan uji statistik Crobach alpha. Suatu Konstruk atau variabel dinyatakan reliabel jika memberikan nilai Crobach alpha $>0,60$.

Menurut Ghozali (2018), Uji Normalitas bertujuan untuk menguji apakah model regresi, variabel pengganggu atau residual memiliki distribusi normal, Salah satu cara termudah untuk melihat normalitas residual adalah dengan melihat grafik histogram yang membandingkan antara data observasi dengan distribusi yang mendekati distribusi normal.

Menurut Ghozali (2018:107) Multikolonieritas bertujuan untuk menguji apakah model regresi ditemukan adanya korelasi antar variabel bebas independen, Nilai cutoff yang umum dipakai untuk menunjukkan adanya multikolonieritas adalah nilai Tolerance $\leq 0.10$ atau sama dengan nilai $\mathrm{VIF} \geq 10$.

Menurut Ghozali (2018) uji autokorelasi bertujuan untuk menguji apakah dalam model regresi linier ada korelasi antara kesalahan penganggu periode $t$ dengan kesalahan pengganggu pada periode $\mathrm{t}-1$. Autokorelasi muncul karena observasi yang berurutan sepanjang waktu berkaitan satu sama lainnya, Deteksi autokorelasi yaitu dengan Uji Durbin-Watson (DW).

Menurut Ghozali (2018:137) Uji heteroskedastisitas bertujuan menguji apakah dalam model regresi terjadi ketidaksamaan varian dari residual satu pengamatan ke pengamatan yang lain.

Menurut Imam Ghozali (2018 : 95) Analisis regresi pada dasarnya adalah studi mengenai ketergantungan variabel dependen (terikat) dengan satu atau lebih variabel independen (variabel penjelas/bebas), dengan tujuan untuk mengestimasi dan atau memprediksi rata-rata populasi atau nilai ratarata variabel dependen berdasarkan nilai variabel independen yang diketahui, dengan menggunakan rumus :

$$
\mathrm{Y}=\mathrm{a}+\mathrm{b}_{1} \mathrm{X}_{1}+\mathrm{b}_{2} \mathrm{X}_{2}+\mathrm{e}
$$

Menurut Imam Ghozali (2018:97), Koefisien determinasi $\left(\mathrm{R}^{2}\right)$ pada intinya mengukur seberapa jauh kemampuan model dalam menrangkan variasi variabel dependen Sedangkan untuk melihat seberapa besar tingkat pengaruh variabel independen terhadap variabel dependen secara parsial digunakan koefisien determinasi (Kd) dengan rumus sebagai berikut:

$$
\mathrm{Kd}=\mathrm{R}^{2} \times 100 \%
$$

Menurut Ghozali (2018:99), Uji statistik t pada dasarnya menunjukan seberap jauh pengaruh satu variabel penjelas/independen secara individual dalam menerangkan variasi variabel dependen.

Perumusan Hipotesis untuk uji $\mathrm{t}$ :

Hipotesis $1: \mathrm{Ha}: \mathrm{b} 1 \neq 0$

Hipotesis $2: \mathrm{Ha}: \mathrm{b} 2 \neq 0$

Uji hipotesis seperti ini dinamakan uji signifikansi secara keseluruhan terhadap garis regresi yang diobservasi maupun estimasi, apakan $\mathrm{Y}$ berhubungan linear terhadap $\mathrm{X}_{1}, \mathrm{X}_{2}$.

\section{HASIL DAN PEMBAHASAN}

Tabel 1. Karakteristik responden berdasarkan

\begin{tabular}{|c|c|c|}
\hline Karaktersitik & N & Presentase \\
\hline Jenis kelamin & 94 & $100 \%$ \\
\hline Usia & 94 & $100 \%$ \\
\hline Pekerjaan & 94 & $100 \%$ \\
\hline
\end{tabular}

Menjelaskan bahwa responden jenis kelamin laki-laki sebanyak 54 jiwa, data presentase terhitung $(57,4 \%)$ sedangkan responden dengan jenis kelamin wanita sebanyak 40 jiwa, terhitung dengan data presentase $(42,6 \%)$ dan keseluruhan dari data 


\section{Journal MISSY}

\section{(Management and Business Strategy)}

Vol. 1, Nomor. 2 November 2020

ISSN : 2775-3700

responden dengan jenis kelamin sebanyak 94 jiwa.

Jumlah responden denga usia 15-20 tahun sebanyak 37 jiwa, dengan dipresentasekan $(39,4 \%)$ dan responden dengan usia 20-25 tahun sebanyak 46 jiwa, dengan presentase $(48,9 \%)$ dan dengan responden usia 25-30 tahun sebanyak 11 jiwa, dengan memiliki presentase $(11,7 \%)$. Maka peneliti dapat menyimpulkan, bahwa pengguna produk Three Second diKota Cilegon mayoritasnya adalah Usia 20-25 tahun.

Bahwa Jumlah Responden dengan Status Pelajar 49 jiwa dengan Presentase (52,1\%), Responden dengan status pekerjaan karyawan 16 jiwa dengan presentase (17.0\%), sedangkan Responden dengan Status Pekerjaan Wiraswasta 13 jiwa dapat dipresentasikan (13,8\%), dan Status Responden dengan lain-lain (D1l) adalah 16 jiwa dengan presentase $(17,0 \%)$.

\section{Uji Validitas}

Tabel 2. Uji validitas variabel citra merek (X1)

\begin{tabular}{|l|l|l|l|}
\hline NO & $\begin{array}{l}\text { Corrected Item- } \\
\text { Total Correlation }\end{array}$ & $\begin{array}{l}\text { tabel } \\
(\mathbf{n - 2} 94-2=92)\end{array}$ & Ket. \\
\hline CM1 & 0,729 & 0,202 & Valid \\
\hline CM2 & 0,818 & 0,202 & Valid \\
\hline CM3 & 0,779 & 0,202 & Valid \\
\hline CM4 & 0,612 & 0,202 & Valid \\
\hline CM5 & 0,703 & 0,202 & Valid \\
\hline CM6 & 0,578 & 0,202 & Valid \\
\hline
\end{tabular}

Tabel 3. Uji validitas variabel potongan harga (X2)

\begin{tabular}{|l|l|l|l|}
\hline NO & $\begin{array}{c}\text { Corrected Item- } \\
\text { Total Correlation }\end{array}$ & \multicolumn{1}{|c|}{$\begin{array}{c}\text { rabel } \\
(\mathbf{n - 2} 94-2=92)\end{array}$} & Ket. \\
\hline PH7 & 0,724 & 0,202 & Valid \\
\hline PH8 & 0,844 & 0,202 & Valid \\
\hline PH9 & 0,770 & 0,202 & Valid \\
\hline PH10 & 0,603 & 0,202 & Valid \\
\hline PH11 & 0,698 & 0,202 & Valid \\
\hline
\end{tabular}

Tabel 4. Uji Validitas Variabel Minat Beli (Y)

\begin{tabular}{|c|l|l|l|}
\hline NO & $\begin{array}{c}\text { Corrected Item- } \\
\text { Total Correlation }\end{array}$ & $\begin{array}{c}\text { rtabel } \\
(\mathbf{n - 2} \text { 94-2 } \mathbf{9 2})\end{array}$ & Ket. \\
\hline MB12 & 0.721 & 0,202 & Valid \\
\hline MB13 & 0,719 & 0,202 & Valid \\
\hline MB14 & 0,697 & 0,202 & Valid \\
\hline MB15 & 0,696 & 0,202 & Valid \\
\hline
\end{tabular}

\begin{tabular}{|l|l|l|l|}
\hline MB16 & 0,739 & 0,202 & Valid \\
\hline MB17 & 0,709 & 0,202 & Valid \\
\hline MB18 & 0,653 & 0,202 & Valid \\
\hline
\end{tabular}

Sumber : Hasil Olah Data SPSS

\section{Uji Reliabilitas}

Tabel 5. Uji reliabilitas

\begin{tabular}{|l|l|l|l|}
\hline Variabel & $\begin{array}{l}\text { Nilai } \\
\text { Crobach's } \\
\text { Alpha }\end{array}$ & $\begin{array}{l}\text { Perbandingan } \\
\text { Pada Scale Of } \\
\text { thumb nunally }\end{array}$ & Ket. \\
\hline Citra Merek (X1) & 0,796 & 0,60 & Reliabel \\
\hline Potongan Harga (X2) & 0,776 & 0,60 & Reliabel \\
\hline Minat Beli (Y) & 0,830 & 0,60 & Reliabel \\
\hline
\end{tabular}

Sumber : Olah data spss 2020

\section{Uji Regresi Berganda}

Tabel 6. Regresi berganda

\begin{tabular}{|c|c|c|c|c|c|c|}
\hline \multicolumn{7}{|c|}{ Coefficientsa } \\
\hline \multirow{2}{*}{\multicolumn{2}{|c|}{ Model }} & \multicolumn{2}{|c|}{$\begin{array}{l}\text { Unstandardized } \\
\text { Coefficients }\end{array}$} & \multirow{2}{*}{\begin{tabular}{|c|}
$\begin{array}{l}\text { Standardized } \\
\text { Coefficients }\end{array}$ \\
Beta \\
\end{tabular}} & \multirow[b]{2}{*}{$\mathbf{T}$} & \multirow[b]{2}{*}{ Sig. } \\
\hline & & B & Std. Error & & & \\
\hline \multirow[t]{3}{*}{1} & (Constant) & 3.526 & 3.689 & & .956 & .342 \\
\hline & TCM & .441 & .109 & .372 & 4.034 & .00 \\
\hline & TPH & .669 & .156 & .396 & 4.297 & .00 \\
\hline
\end{tabular}

a. Dependent Variable: TMB

Sumber : Hasil Olah Data SPSS

Persamaan Regresi diatas maka dapat diuraikan sebagai berikut :

Koefesiens konstanta $=3.526$ hal ini berarti jika nilai dari Citra Merek $\left(\mathrm{X}_{1}\right)$ dan Potongan Harga $\left(\mathrm{X}_{2}\right)$ sama dengan nol, maka tingkat atau besaranya Minat Beli (Y) sebesar 3.526. Koefesien konstanta $b_{1}=0,441$ bahwa apabila nilai Citra Merek $\left(\mathrm{X}_{1}\right)$ mengalami kenaikan sebesar $1 \%$ Sementara variabel independen lainnya bersifat tetap maka tingkat Minat Beli (Y) akan mengalami kenaikan sebesar $44,1 \%$. Koefesien regresi Potongan Harga (X2) sebesar 0,669 menyatakan bahwa setiap kenaikan $1 \%$ maka tingkat Minat Beli (Y) mengalami kenaikan sebesar $66,9 \%$.

\section{Uji Signifikasi Parameter Individual Uji t}

Kegunaan dari pada uji t, untuk mengetahui apakah secara individu (parsial) variabel independen mempengaruhi variabel dependen secara signifikan atau tidak. Hasil 
daripada output Spss dapat dilihit sebagai berikut.

Tabel 7. Uji T

\begin{tabular}{|c|c|c|c|c|c|c|}
\hline \multicolumn{7}{|c|}{ Coefficientsa } \\
\hline & \multirow[b]{2}{*}{ Model } & \multicolumn{2}{|c|}{$\begin{array}{l}\text { Unstandardized } \\
\text { Coefficients }\end{array}$} & \multirow{2}{*}{\begin{tabular}{|c|}
$\begin{array}{c}\text { Standardized } \\
\text { Coefficients }\end{array}$ \\
Beta \\
\end{tabular}} & \multirow[b]{2}{*}{$\mathbf{T}$} & \multirow[b]{2}{*}{ Sig } \\
\hline & & B & Std. Error & & & \\
\hline \multirow[t]{3}{*}{1} & (Constant) & 3.526 & 3.689 & & .956 & .000 \\
\hline & TCM & .441 & .109 & .372 & 4.034 & .000 \\
\hline & TPH & .669 & .156 & .396 & 4.297 & .000 \\
\hline
\end{tabular}

Sumber : Olah data Spss 2020

Dapat dilihat pada tabel diatas bahwa untuk uji $\mathrm{t}$ yang pertama, dapat diketahui bahwa nilai koefesien regresi variabel Citra Merek $\left(\mathrm{X}_{1}\right)$ adalah 441 bernilai positif. Hasil Perhitungn menunjukan nilai signifikansi $0,00<0,05$ atau $\mathrm{T}_{\text {hitung }} 4,034>1,661 \mathrm{~T}_{\text {tabel }}$ dengan demikian Ha diterima, yang artinya Citra Merek berpengaruh signifikan bernilai positif terhadap Minat Beli.

Uji t yang pertama, diketahui bahwa nilai koefesien regresi variabel Potongan Harga $\left(\mathrm{X}_{2}\right)$ dengan nilai 669 bernilai positif. Hasil perhitungan menunjukan nilai signifikansi $0,00<0,05$ atau $\mathrm{T}_{\text {hitung }} 4.297>$ 1,661 $\mathrm{T}_{\text {tabel }}$ dengan demikian Ha diterima yang artinya Potongan Harga berpengaruh signifikan bernilai positif terhadap Minat Beli.

\section{Uji Signifikansi Simultan (Uji F)}

\begin{tabular}{|l|l|l|l|l|l|r|}
\hline \multicolumn{7}{|c|}{ ANOVAa } \\
\hline \multicolumn{2}{|c|}{ Model } & $\begin{array}{c}\text { Sum of } \\
\text { Squares }\end{array}$ & Df & $\begin{array}{c}\text { Mean } \\
\text { Square }\end{array}$ & F & Sig. \\
\hline \multirow{2}{*}{1} & Regression & 468.203 & 2 & 234.102 & 14.906 & $.000 \mathrm{~b}$ \\
\cline { 2 - 7 } & Residual & 1429.201 & 91 & 15.706 & & \\
\cline { 2 - 7 } & Total & 1897.404 & 93 & & & \\
\hline a. Dependent Variable: TMB & & & \\
\hline \multicolumn{2}{|l|}{ b. Predictors: (Constant), TPH, TCM } \\
\hline
\end{tabular}

Sumber : Olah data Spss 2020

Pengujian penagruh variabel terkaitnya dilakukan dengan menggunakan uji f. Hasil Perhitungan Statistik menunjukan
$14.906>3,10 \mathrm{~F}_{\text {tabel }}$ dengan tingkat signifikan sebesar 0,000<0,05 maka Ho ditolak. Maka dengan ini dapat disimpulkan bahwa variabel Citra Merek $\left(\mathrm{X}_{1}\right)$ dan Potongan Harga $\left(\mathrm{X}_{2}\right)$ secara simultan berpengaruh signifikan terhadap Minat Beli (Y).

\section{KESIMPULAN}

Hasil analisis mengenai faktor-faktor yang memperngaruhi Minat Beliadalah Variabel Citra Merek, Citra Merek mempengaruhi minat beli terhadap produk Three Second yang berada di Kota Cilegon, Adapun Presentase dari Citra Merek tersebut adalah 314,66 yang demikian dapat dikategorikan Cukup Baik. Dengan melihat indikator yang tinggi terdapat pada indikator Brand Benefit \& Competence dengan skor 352 , Dengan jumlah skor yang terdapat pada variabel Citra Merek yang diberikan oleh Responden Three Second diKota Cilegon adalah Sebesar 1888. Mengenai faktor-faktor yang mempengaruhi Minat Beli pada Three Second diKota Cilegon adalah Variabel Potongan Harga, adapun Presentase dari Variabel Potongan Harga Tersebut adalah 313,4 yang dapat dikategorikan Cukup Baik. Melihat indikator tertinggi terdapat pada indikator jenis produk yang mendapatkan potongan harga dengan skor 323 Dengan jumlah skor yang ada pada Potongan Harga dan diberikan oleh Responden Three Second diKota Cilegon adalah 1567. Dan Dengan Faktor-faktor yang mempengaruhi Minat Beli tersebut adalah dengan menjelaskan variasi-variasi yang terdapat pada Minat Beli itu sendiri, adapun presentase yang didapatkan oleh Minat Beli tersebut adalah 316 yang dapat dikategorikan Cukup Baik. Melihat indikator tertinggi yang terdapat pada indikator minat beli yaitu indikator miant transaksional dengan skor 333 Dengan jumlah skor yang didapatkan dan diberikan oleh 
responden three second diKota Cilegon sebesar 2212.

\section{DAFTAR PUSTAKA}

Anung, Pramudyo. 2016. Pengaruh Citra Merek Terhadap Loyalitas Melalui Kepuasan Sebagai InterveningStudi pada Mahasiswa Perguruan Tinggi Swasta di Yogyakarta. (JBMA) - Vol. I, No. 1, Agustus 2012 ISSN : 22525483.

Agus, et all. 2019. Pengaruh Diskon Pada Aplikasi e-Wallet terhadap Pertumbuhan Minat Pembelian Implusif Konsumen Milenial di Wilayah Tangerang.Jurnal Sains Manajemen Volume 5 No 2 Desember (2019).

Baskara, 2018.Pengaruh Potongan HargaDiscount Terhadap Pembelian Tidak TerencanaImpulse Buying. Jurnal Management Vol 5, No 2 (2015) Oktober.

Firmansyah, Anang. (2019). Pemasaran Produk dan Merek (Planning \& Strategy) : Penerbit Deepublish (CV Budi Utama ).

Ghozali, Imam. (2018). Aplikasi Analisis Multivariate Dengan Program IBM SPSS 25. Edisi 9Penerbit : Universitas Diponegoro.

Ghozali, Imam. (2016). Desain Penelitian Kuantitatif dan Kualitatitif : Penerbit Yoga Pratama Semarang.

Kotler, Philipdan Kevin Lane Keller.(2012). Marketing Management 13. New Jersey : Pearson Prentice Hall, Inc.

Machfoedz, Mahmud. (2010). Komunikasi Pemasaran Modern Yogyakarta : Penerbit Cakra ilmu.

Maghfiroh, at All.2016. Pengaruh Citra Merek Terhadap Minat beli dan Keputusan Pembelian (Survei Pada Mahasiswa Program Studi
Administrasi Bisnis Tahun Angkatan 2013/2014 Fakultas Ilmu Administrasi Universitas Brawijaya Malang Pembeli Indosat Ooredoo).Jurnal Administrasi Bisnis (JAB) Vol. 40 No.1 November (2016).

Prabowo, dan Nurhadi. 2016. Pengaruh Citra Merek, Kualitas Produk, PersepsidanWord Of Mout Terhadap Minat Beli (Studi pada Mahasiswa Fakultas Ekonomi UNY Pengguna iPhone). Skripsi UNIVERSITAS NEGERI YOGYAKARTA (2016).

Prabarini, at All.2018.Pengaruh Promosi dan Potongan Harga Terhadap Keputusan Pembelian KonsumenProduk Kecantikan Wardah Di Toserba Borobudur Kediri. (JIMEK) Volume.1 Nomor. 2 Desember 2018, E-ISSN : 2621-2374.

Rachmat, Kriyantono. Teknik Praktis Riset Komunikasi.(Jakarta: Kencana, 2006) hlm 153.

Sudrajat, at All. 2017. Pengaruh Potongan Harga Terhdap Minat Beli(Studi Pada Potongan Harga di Iklan Televisi Bukalapak.com Versi Hari Belanja Online Nasional 2015 terhadap Minat Beli Remaja di Kota Bandung). ISSN : 2355-9357 e-Proceeding of Management : Vol.4, No.1 April (2017).

Tjiptono, Fandy. (2015). Strategi Pemasaran, Edisi 4,Penerbit : Andi, Yogyakarta.

Sumber Lain :

Pengaruh harga (price) Kualitas Pelayanan (service quality) dan kepuasaan pelanggan (Costumer satisfaction) terhadap loyalitas pelanggan Gojek di DKI Jakarta. http://repository.fe.unj.ac.id/6349/5/C hapter\%20III.pdf. (Diakses pada tanggal 20 Juni 2020). 


\section{Journal MISSY}

(Management and Business Strategy)

Vol. 1, Nomor. 2 November 2020

ISSN : 2775-3700

Price Discount, dan Bonus Pack Terhadap Impluse

Buying.https://elib.unikom.ac.id/down load.php?id=362107. (Diakses pada tanggal 30 Juni 2020).

Place Marketing, Service quality dan Brand Image terhadap Costumer Loyal.http://library.binus.ac.id/eColls/ eThesisdoc/Bab2DOC/2013-1-00231MN\%20Bab2001.doc(Diakses pada tanggal 5 Juli 2020). 